\title{
Teaching Biology Practical Lessons in Secondary Schools: A Case Study of Five Mzilikazi District Secondary Schools in Bulawayo Metropolitan Province, Zimbabwe
}

\author{
Edson C. Mwangu \\ Lwazi Sibanda \\ Department of Science, Mathematics and Technology Education, \\ National University of Science and Technology, \\ P. O. Box AC939, Ascot Bulawayo, Zimbabwe
}

Doi: 10.1515/ajis-2017-0020

\begin{abstract}
The study examined how teachers teach Biology practical lessons at Ordinary Level in Mzilikazi District Secondary Schools of Bulawayo Metropolitan Province. Qualitative approach and case study design were adopted. Data was collected using document analysis and semi-structured interviews conducted with purposively selected five Biology teachers, five Heads of Science Department from five schools, and one Science Subject Inspector. Data were thematically analysed. The study revealed that teachers used both teacher-centred and student-centred methods in teaching Biology practical lessons and various factors constrained the teaching of practical lessons. The study concluded that some Biology teachers in selected schools did not conduct practical lessons in line with the Ministry of Primary and Secondary Education expectations. The study recommends that the Ministry of Primary and Secondary Education should continue equipping teachers with knowledge and skills of teaching Biology practical lessons through workshops and other staff development programmes.
\end{abstract}

Keywords: biology practical lessons, ordinary level, secondary school, teaching

\section{Introduction}

Worldwide, it has been recognised that science education is indispensable and should be effectively taught in schools. Studies conducted globally have shown the pivotal role played by laboratory work in enhancing science concepts' teaching and learning in educational institutions (Motlhabane \& Dichaba, 2013). A successful practical lesson should be inquiry based than deductive based learning (Rocard, Csermely, Lenzen \& Hemmo, 2007). There is unanimous agreement among educationists universally that for students to better understand the natural phenomena and learn how science attempts to understand and clarify these issues, science teachers should afford students opportunities to engage with and fully participate in practical work (Gott \& Duggan, 2009). Nevertheless, the conducting of practical science activities in schools has sparked debate among scholars regarding their specific purpose. The argument among scholars is that the improvement of students' learning about science, may not have much bearing if practical investigations are not well prepared (Millar, 2009).

\section{Background}

Studies reveal that in United Kingdom, practical work been adopted by teachers as a coping 
strategy to deal with heterogeneous group of students (Swain, Mark \& Johnson, 2000). However, teachers' attitude towards practical work is pitiable; as a result they do it to fulfil the minimum requirements of the syllabus (Kibirige \& Teffo, 2014). In South Africa, Dekkers (2005) found that science teachers in Limpopo Province made little use of practical lessons. A study in Kenya by Rutto and Kptingel (2014) has revealed that students are less exposed to practical work during science lessons. In Ghana, countless teachers have on no occasion conducted far more than rudimentary repetition of theory work which is a requirement for examinations (Perry, 2015). Thus, the way some science teachers teach science lessons encourages memorisation instead of sound investigative oriented learning and fails in affording students chances in planning inquiries and performing own experiments, manipulating materials and apparatus to enhance the construction of own knowledge of phenomena and related scientific concepts by students (Hofstein \& MamlokNaaman, 2007).

In Zimbabwe, the Ministry of Education Circular No. 6 of 2001 stipulates that an Ordinary Level Biology timetable should have at least two theory periods and four practical periods per week. The Science, Innovation and Technology Policy (2012) states that practical experiments should exploit the background experiences of students and encourage interest across gender, science subjects should be taught in a way that permits every student to undertake direct practical experimentation frequently. Nevertheless, most learners countrywide have continued to perform poorly in Biology Paper four which is a practical examination paper as compared to Paper one and two which are theory examination papers (ZIMSEC Examiners Reports, 2014).

In response to the problem, the Ministry of Primary and Secondary Education (MOPSE) has put in place a Science Education In-Service Teacher Training Programme for Ordinary Level science teachers under the Better Schools Programme Zimbabwe. Additionally, annual conferences on science and mathematics education have been conducted to educate teachers on new methodologies of teaching science subjects (Mwenje, 2012).

Despite the measures taken by MOPSE to improve the teaching of Biology practical lessons in secondary schools, there has been growing concern among students and parents as ZIMSEC Report for 2012 revealed the lowest pass rate of $38.38 \%$ in Ordinary Level Biology. This was the lowest pass rate in the past five years (Ruparanganda, Rwodzi \& Mukundu, 2013). Furthermore, the ZIMSEC Examiners' Report for 2014 raised concern on the low performance of students countrywide in Biology Paper four (ZIMSEC, 2014). Given the above concerns and observations, it is not clear how Biology practical lessons are taught in secondary schools. That is, although MOPSE has put in place some measures to equip teachers with knowledge and skills on how to conduct Biology practical lessons, it is not clear how teachers teach these lessons.

\section{Literature Review}

\subsection{Teaching Biology practical lessons}

Biology practical lessons are important in order to understand biological concepts. If science education aims to enhance the understanding of the natural world by students and how it functions, then the students have to experience and observe the relevant science phenomena. Recent studies advocate for a change in teaching methods so that students participate fully and understand difficult science concepts (Millar, 2010). Students should understand processes and structures; develop skills in manipulation, processing of science information and conducting scientific investigations. Hence, the teaching methods such as learner design, reciprocal, inclusion, divergent and self-check could enhance the teaching of Biology practical lessons (Capel, Leask \& Turner, 2009).

Ormrod (2000) insists that in science education, students are exposed to first-hand experience of the scientific inquiry process as well as constructing conceptual knowledge through a designed student-centred investigative method. Hence, the learning process is usually considered more important than the acquisition of factual knowledge in student-centred methods. Discovery learning as an inquiry-based learning method enables students to be actively involved in investigating a topic or problem, obtaining appropriate information, interpreting causes and effects where necessary, and reaching the conclusions or solutions. 
However, it has been observed that inquiry-based instruction requires the most expert teachers and there is need to prepare novice teachers in several domains of teaching, including pedagogic content knowledge, students' knowledge, and classroom management knowledge. In Zimbabwean secondary schools, the majority of Biology teachers are not experts, they are degree holders who have deep knowledge in content but lack teaching methodology (Mulkeen, 2010).

A study conducted by Obiekwe and Chinwe (2012) in Nigeria on the teaching of biological concepts using the 5E (Engagement, Exploration, Explanation, Elaboration and Evaluation) model revealed that students who were exposed to the $5 \mathrm{E}$ method achieved better results than those whose teachers used the lecture method. Some teachers laid too much emphasis on content and the use of 'chalk and talk' approach which does not enhance the teaching and learning of Biology. This slackness and 'shy- away' attitude from activity based-approach of instructional delivery has led to abstraction, which makes the students passive and more inclined to rote memorisation (Obiekwe \& Chinwe, 2012). Such teacher-centred method that puts the students as passive recipients of knowledge and the teacher as the only source of knowledge might not improve achievement or stimulate positive attitude towards Biology practical lessons (Nwagbo, 2006).

\subsection{Instructional materials}

For the Biology practical lessons to be effectively taught, teachers are encouraged to use instructional materials. Some of the materials that could be used by teachers include virtual laboratory, realia, models and mock-ups, phenomenal materials and manipulative materials (Kishor, 2003).

Many scholars view virtual reality technology as a provision of new insights to support education. Collaborative learning environment where students are actively involved in their learning through use of animations and simulations for abstract topics provides students with opportunities to easily construct and comprehend challenging concepts (Tüysüz, 2010). Using virtual laboratories or simulation programmes, minimises problems experienced in ordinary laboratory applications and results in accomplishment of educational goals. Thus, a study conducted in Turkey by Tüysüz (2010) revealed that use of virtual laboratory improved attainment levels of students and influenced the attitudes of students positively towards science education.

Realia such as specimen, exhibits, and cut-away objects have great value in every subject including Biology. The use of realia can do much to promote the student's interest in life science. Realia eliminate distortion in student's knowledge on the topics being taught. Additionally, phenomenal materials such as community engagement, field trips and service learning result in educational benefits by enabling students to interact with community members, exposing students to environments which might be hard or impossible to imitate in the classroom (Tortop, Uzunkavak \& Ozek, 2009). One way to increase student engagement is the use of manipulative materials during instruction (Bello, 2015). A study by Ruffato (2012) in United States of America, showed that when students were using hands-on methods of learning biological processes, they were more engaged than with previously used methods like lecture and following drawings on the board and performed well in short term assessments of knowledge.

\subsection{Assessment of practical work}

Assessment is indispensible in the teaching and learning process. Thus, Direct Assessment of Practical Skills (DAPS) and Indirect Assessment of Practical Skills (IAPS) are the two methods of assessment of practical activities that have been identified. Basically, DAPS is when marks are only obtained when a student is assessed specifically on their practical skills whereas IAPS is done when a student is credited for producing a report about the science practical lesson they have undertaken (Abrahams, Reiss \& Sharpec, 2013). Practical skills are better assessed directly rather than indirectly (Abraham et al., 2013). However, assessment of science practical lessons is a flawed process the world over. Research studies indicate that teachers put more emphasis in preparing students to perform well in what constitutes $25 \%$ of their final grade which is a narrow range of externally-set practicals. Teachers who, under high stakes system, are under massive 
pressure to award students maximum marks, internally assess students on their planning and analytical abilities, not on their technical skills (Gatsby Foundation, 2012). Hence, for assessment to be effective, teachers should know what they should assess, whether it is process skills, conceptual understanding, practical skills or procedural understanding (Gott \& Duggan, 2009).

\subsection{Challenges faced in the teaching Biology practical lessons}

The teaching of Biology practical lessons is not spared from drawbacks which inhibit the achievement of set goals. The factors such as unavailability of science teachers in schools, lack of materials, lack of funds and time have constrained the teaching of Biology practical lessons. Consequently, many students fail to perform well in Biology because of inadequacy of instructional material such as laboratories, chemicals, models, apparatus, local specimens and shortage of textbooks. Lack of allocated practical lesson time and irregularity of carrying out practical Biology lessons by teachers affect student performance and understanding (Owino, Ahmad \& Yungungu, 2014). Hence, in light of this backdrop, this study intended to respond to the following research questions: (i) How do teachers teach Ordinary Level Biology practical lessons in Mzilikazi District Secondary Schools? and (ii) What challenges are encountered by teachers in the teaching of Ordinary Level Biology practical lessons in Mzilikazi District Secondary Schools?

\section{Research Methodology}

The study adopted a qualitative approach, which is interpretive research that relies on observers defining and redefining the meanings of what they have observed (Stake, 2010). This approach enabled the researchers to be data collection instruments with sustained and intimate contact with participants of the study (Merriam, 2009). This study also employed a case study design which is an in-depth study of the interactions of a single instance in an enclosed system (Opie, 2004). A case study was used to explore how teachers teach Biology practical lessons in Mzilikazi District Secondary Schools and the challenges they encounter in conducting practical lessons.

The target population comprised ten secondary schools in Mzilikazi District with six hundred and twelve Ordinary Level teachers and the science inspector for Bulawayo Metropolitan Province. The sample constituted ten Ordinary Level Biology teachers who were purposively selected from five secondary schools in Mzilikazi District.

The research instruments used were semi-structured face to face interview and document analysis. The semi-structured interview allowed the researchers a certain degree of flexibility to respond to the answers of the interviewees and thus developed the themes and issues as they arose (Headlam \& MacDonald, 2006). Document analysis triangulated where possible what originated from face to face interviews. Qualitative data were coded systematically and thematically analysed to address the research questions. To ensure credibility and trustworthiness, the researchers used member checks and triangulation of data (Polit \& Beck, 2006). Regarding ethical issues, the researchers sought permission from MOPSE to conduct the study and were granted. Issues of consent, honesty, confidentiality and anonymity were also taken into account when carrying out the study.

\section{Results}

The study results are presented under the following themes: lesson planning, time allocation, teaching methods, instructional materials, classroom management, assessment of practical work and challenges encountered by teachers. The identification of participants is as follows: SSI = Science Subject Inspector, HSD1-HSD5 = Heads of Science Department, ST1-ST5 = Science Teachers, A-E = Schools.

\subsection{Lesson planning}

The participants were asked how they plan for practical activities and in response most teachers 
said they check if resources are available and use laboratory technicians in setting up experiments. Presented are some of their responses:

\begin{abstract}
ST5: We plan with the laboratory technician, give material required for that particular day, check the lesson time on the timetable and laboratory technician prepares for the practical lesson.

HSD3: Planning involves first identifying the aim, secondly, identifying the materials, methods and apparatus available, checking if substitutes for them are available, and after that you look at the method, and then carry out the experiment before taking it to students.
\end{abstract}

From the teachers' responses it seems they plan for lessons but it is difficult to say with certainty if the practical lessons are actually planned for, as the responses given by the participants, do not detail exactly what is done. However, documentary evidence confirm that all teachers in schools A-E had planned for their practical lessons for the first term and revealed that teachers (ST1-ST5) and HSDs (HSD1- HSD5) had placed requisition orders for their lesson activities. Only teachers in Schools B and C planned for field trips. However, detailed steps for conducting the activities were not clearly illustrated. Furthermore, responses from participants suggest that most of the teachers expect the laboratory technicians to do the planning and carrying out the pre-testing, yet it is supposed to be a coordinated activity.

Nonetheless, SSI said: Usually teachers do not want to plan. They just want to get into class and pick the apparatus required and try to do the practical lesson in front of the students. Under any circumstances it will not work out because they will not have planned for it.

\title{
5.2 Time allocation
}

In response to the question pertaining to time allocation for Biology practical lessons, all participants mentioned that they teach five periods per week except HSD4 and ST3 who teach four periods per week. Most of the participants said that they allocate two periods per week for Biology practical lessons. The participants were further asked if the allocated time was enough and they all agreed that the time allocated was not enough. Their responses are as follows:

ST5: Time is not enough. Four periods is not enough. Furthermore time is taken by sports. The last two weeks we did not teach but concentrated on sports. Another week, for two days, we attended Teacher Professional Standards workshops. Sometimes the administration calls you for other duties to attend to. By the time you are through with the administration, lesson is over. taught.

SSI however argued that the allocated time was enough and depended on the topic being

\subsection{Teaching methods}

The participants were asked about the methods they used in teaching Biology practical lessons. They revealed that Biology teachers used both teacher-centred and student-centred methods during practical lessons. It was shown from the responses that only one school used an ecological garden in teaching Biology practical lessons. Their remarks are cited below:

ST1: I will answer in two ways, teacher centred approach and the chalk and talk approach. This ensures that one spends less time and more content of syllabus is covered on allocated time.

ST2: We put them into groups which allows working with resources that we have. I also integrate them according to their different strengths. I also make sure that all are involved in the practical lesson activities.

HSD5: Mostly, teachers do demonstration, but rarely find students doing practical lessons on their own.

HSD4: At times I use the discovery method. Students first discuss on their own, then as they discuss I come in and ask questions to encourage critical thinking.

ST2: I use hands on approach to help students understand better. It is because of that philosophy when I hear I forget and when I do I remember. 


\subsection{Instructional materials}

The participants were asked to give their views on the most effective instructional materials used in teaching Biology practical lessons. It came out from the participants that most schools use textbooks, charts, posters, models and a few use e-learning software or virtual laboratories. They expressed that:

ST3: I use charts, models, to allow the students to identify the different parts they have to master. I use PowerPoint and video animations to make students understand better. The animations arouse interest in students.

SSI: Some schools have e-learning software; they show videos of topics they will be teaching. Not all schools have e- learning software, most schools use textbooks.

\subsection{Classroom management}

Participants were asked how they managed their classes during Biology practical lessons. All participants agreed that they grouped students into small manageable groups since their classes were large. The responses given are as follows:

ST1: We divide them into manageable groups of 10 or 5.

However, SSI highlighted that: A few teachers are managing but most are not because when they look at the numbers, they get hounded, they don't like practical lessons and resort to demonstration. Others call the whole class to the front desk, for an activity, unfortunately students at the back will not observe or follow and only those in the front will benefit.

\subsection{Assessment of practical work}

In response to how the participants assessed students in practical lessons, it emerged that teachers ask oral questions, give exercises and tests to ascertain whether students have grasped the concepts during Biology practical lessons. However, it has been noted that the questions are limited to specific stages and not all the stages of the practical lessons. This suggests that the approach does not give a holistic assessment. They gave the following remarks:

ST1: I call any student at random to recap the lesson or I ask oral questions and assess student responses. If time permits a short exercise is given.

ST3: I ask questions regarding their observations, or questions that demand application of that knowledge. Normally, I give an exercise at the end of the practical lesson, which in most cases can either be group work or individual work.

ST2: I usually ask them to come and demonstrate a component of the practical activity performed. They can also explain the method used and observations made.

HSD2: At times students record observations and then I mark, give questions on the practical lesson. I also assess their skills. Students are asked to account for results. Questions on practical lessons can be repeated during tests to check if objectives have been achieved.

Documents analysed show that exercises and tests are given but rarely does evidence of assessment of practical activities cover all the stages of the lesson activities. SSI commented that it is not clear how marks are allocated when a test or an exercise is used as a method of assessment.

\subsection{Challenges encountered in teaching Biology practical lessons}

Regarding the challenges encountered in the teaching of Biology practical lessons, all participants stated that lack of resources, facilities, lesson time and large classes were the main challenges faced when teaching practical lessons. They indicated that: 
ST1: Managing large groups is a challenge. We are forced to deal with large groups because of limited resources. Another challenge is time. There are many subjects and activities done by students.

HSD4: The first challenge is abnormally large classes. It is difficult to control a large number in a practical lesson and most of the time is spent on distributing the apparatus to large classes. Another challenge is sharing of classrooms.

HSD5: The shortage of apparatus and large classes are the main challenges we face.

However, SSI cited lack of knowledge as the biggest challenge. Most teachers have degrees but do not have the teaching qualification. They know the content but may not know how to put it across to the students. Due to that fact, they may not give a proper Biology practical lesson because they do not know how to conduct the practical lesson at the level of the student.

\section{Discussion}

From the findings pertaining to the teaching of Biology practical lessons at Ordinary Level in Mzilikazi District Secondary Schools, it emerged that the practical lessons were not given enough teaching time. The finding concurs with observation by Owino et al. (2014) that lack of allocated practical lesson time affects student performance and understanding. The study also established that although there was evidence of planning for Biology practical lessons, the lesson plans lacked detail and in some cases the objectives were poorly defined, especially for field trips. The findings of this study are consistent with Tok's (2010) study conducted in Turkey which revealed that teachers planned for field trips although they faced difficulties in planning for the lessons.

The study established that Biology teachers use both teacher-centred and student-centred methods during practical lessons. It came out that teachers used both the demonstration method and hands on approach. The results of this study confirm what was found by Gorghiu, Draghicescu, Cristea, Petrescu and Gorghiu (2015) in Turkey. The finding of the current study indicated that only one school used an ecological garden when teaching Biology practical lessons. The finding affirms results of the study by Desmond, Grieshop, Subramaniam (2002) that the schools understudy in Ethiopia, Brazil, Cuba, India, Jamaica, and Micronesia had no ecological gardens.

The results of the study show that most schools use textbooks, charts, posters, models and a few schools use e-learning software or virtual laboratories to enhance the teaching of Biology. This finding agrees with Kalinga (2008) who observed that most schools in Tanzania do not use elearning software when teaching science practical lessons but traditional instructional methods such as charts, textbooks, posters and models.

The study found that in all schools grouping students was the common practice of class management when conducting practical lessons in large classes. This finding is consistent with Oprea's (2013) view that group work is a stimulating activity, creating a contagious behaviour and a competitive endeavour in solving complex tasks.

The study established that teachers ask oral questions, give written exercises and tests to ascertain achievement of lesson objectives or mastery of concepts during Biology practical lessons. However, the results revealed that the questions asked are limited to specific stages of a Biology practical lesson activity and not to all the stages of the practical lesson activities. This is in line with the findings of the study by Gatsby Foundation (2012) carried out in the United Kingdom which stated that teachers failed to assess practical skills correctly.

It emerged from the study that teachers experienced various challenges in teaching Biology practical lessons due to lack of resources, facilities, time and large classes. The findings of the study confirm results by Nasri, Yusof, Ramasamy and Halim, (2010) in Malaysia that lack of resources, limited lesson time, administration activities and large classes negatively affected the teaching of Biology practical lessons. The current study further established that lack of knowledge on how to teach Biology practical lessons is the biggest challenge in selected secondary schools. It was found that some Biology teachers held diplomas while others had degrees but did not possess the teaching qualifications. This finding is commensurate with the results of the study by Mulkeen (2010) that teachers in Gambia, Tanzania and Lesotho had diplomas and degrees in Biology specialisation but lacked teaching qualifications. 


\section{Conclusion}

In conclusion, it is evident from the findings of the study that teachers used both teacher-centred and student-centred methods in teaching Biology practical lessons. There was evidence of planning for Biology practical lessons although the lesson plans lacked detail and in some cases the objectives were poorly defined, especially for field trips. A few selected schools used e-learning software or virtual laboratories to enhance the teaching of Biology practical lessons. The teaching of Biology practical lessons in selected schools was constrained by various challenges which encompassed lack of resources, facilities, time, large classes and lack of knowledge on how to teach Biology practical lessons by graduate teachers who did not possess the teaching qualification. Since the study used a small sample, it is recommended that a study using larger population should be conducted in Bulawayo Metropolitan Province Secondary Schools so that the results could be generalised.

\section{References}

Abrahams, I., Reiss, M. J. \& Sharpec, R. M. (2013). The Assessment of Practical Work in School Science. Studies in Science Education, 49(2), 209-251.

Bello, S. (2015). Effect of some teacher factors on the conduct of effective biology practical lesson. Global Advanced Research Journal of Educational Research and Review, 4(3), 048-054.

Capel, S, Leask, M. \& Turner, T. (2009). Learning to teach in secondary schools. New York: Routlegde Publishers.

Dekkers, P. (2005). Teaching teachers NOS: Practical examples and classroom experiences. Science Education International, 18(30), 193-210.

Desmond, D., Grieshop, J. \& Subramaniam, A. (2002). Revisiting garden-based learning in basic education. Rome: Food and Agriculture Organization

Gatsby Foundation (2012). Science for the workplace. London: Gatsby Charitable Foundation.

Gorghiu, G., Draghicescu, L. M., Cristea, S., Petrescu, A. M. \& Gorghiu, L. M. (2015). Problem-Based Learning - An Efficient Learning Strategy In The Science Lessons Context. Procedia Social and Behavioral Sciences, 191, $1865-1870$.

Gott, R., \& Duggan, S. (2009). Problems with the assessment of performance in practical science: which way now? Cambridge Journal of Education, 32(2), 183-201.

Headlam, N. \& MacDonald, S. (2006). Research Methods Handbook: Introductory guide to research methods for social research. Manchester: CLS Publications.

Hofstein, A. \& Maalmlok-Naaman, R. (2007). The laboratory in science education: the state of the art. Chemistry Education Research and Practice, 8(2), 105-107.

Kalinga, E.S. (2008). Development of an interactive e-learning management system (e-Ims) for Tanzanian secondary schools. Division of Techno science Studies School of Technoculture, Humanities and Planning Blekinge Institute of Technology, Sweden.

Kibirige, I. \& Teffo W.L. (2014). Actual and Ideal Assessment Practices in South African Natural Sciences Classrooms. International Journal of Educational Science, 6(2), 509-519.

Kishor, N.(2003). Educational technology. New Delhi: Abhishek publication.

Merriam, S. B. (2009). Qualitative research: A guide to design and implementation. San Francisco, CA: John Wiley \& Sons.

Millar R. (2009). Analysing practical activities to assess and improve effectiveness: The Practical Activity Analysis Inventory (PAAl). Heslington, York: Centre for Innovation and Research in Science Education, Department of Educational Studies, University of York

Millar, R. (2010). Practical work. In J. Osborne \& J. Dillon (Eds.), Good practice in science teaching: What research has to say (2nd Ed.). Maidenhead: Open University Press.

Ministry of Education, Sport, Arts and Culture (2001). Secretary's Circular Number 6 of 2001. Harare: Government Printers.

Motlhabane, A. \& Dibacha, M. (2013). Androgical Approach to Teaching and Learning Practical Work in Science: A Case Study of In-service Training of Teachers. International Journal of Science, 5(3), 201-207.

Mulkeen, A. (2010). Teachers in Anglophone Africa. Issues in teacher supply, training, and management. New York: The World Bank.

Mwenje, E. (2012). Mathematics, Science and Technology Conference. Bindura: Bindura: University of Science Education.

Nasri, N.M., Yusof, Z.M., Ramasamy, S. and Halim, L. (2010). Uncovering problems faced by science teacher. Procedia Social and Behavioral Sciences, 9 (3), 670-673. 
Nwagbo, C. R. (2006). Effects of two Teaching Methods on the Achievement in and Attitude to Biology of Students of Different Levels of Scientific Literacy. International Journal of Educational Research, 45(4), 216-229.

Obiekwe, C. and Chinwe, N. (2012). Effects of the constructivist approach in the teaching of basic ecological concepts in biology. Journal of Science Teachers association of Nigeria, 42 (1), 26-35.

Opie, C. (2004). Doing Educational Research. Thousand Oaks: SAGE Publications.

Oprea, C.G. (2013). The enthusiastic teaching - the actor`s art didactically transposed for teachers. Procedia Social and Behavioral Sciences, 76, $602-607$.

Ormrod, J. E. (2000). Educational psychology: Developing learners (3rd Ed.). Upper Saddle River, NJ: MerrillPrentice Hall.

Owino, O.A., Ahmad, O. \& Yungungu, A. (2014) 'An investment of factors that influence performance in KSCE biology in selected secondary schools in Nyakach District, Kisumu Country. Kenya' Journal of Education and Human Development, 3(2), 957-977.

Perry, E. (2015). Developing practical work in Ghana. Ghana Science Resource Centres.

Polit, D. F. \& Beck, C.T. (2006). Essentials of Nursing Research Appraising Evidence for Nursing Practice. New York: Lippincott Williams \& Wilkins.

Rocard, M., Cesrmley, P., Lenzen, D. \& Hemmo, V. (2007). Science education now: A renewed pedagogy for the future of Europe. Bruxelles: European Comission.

Ruffato, J.M. (2012). The impact of manipulative models on student understanding of, engagement in, and confidence in abstract biological processes. Unpublished Master of Science Education Dissertation, Montana State University: Bozeman, Montana.

Ruparanganda, F., Rwodzi, M. \& Mukundu, C.K. (2013).Project Approach as an Alternative to Regular Laboratory Practical Work in the Teaching and learning of Biology in Rural Secondary Schools in Zimbabwe. International Journal of Education and Information Studies, 3(1), 13-20.

Rutto, K.P., \& Kptingel, P. (2014). Challenges facing laboratory practical approach in physics instruction in Kenya District Schools. International School of Achievements in Research and Technology, 3 (4), 650675.

Stake, R. E. (2010). Qualitative research: studying how things work. Thousand Oaks: Sage Publications.

Swain, J., Mark, M. \& Johnson, S. (2000). Developments in Science Teachers Attitudes to Aims of Practical Work: Continuity and Chase. Teacher Development, 4(2), 425-439.

The Science and Technology Human Capital Development Unit, UNCST (2012). The quality of science education in Uganda science and technology policy coordination division. Kampala: Uganda National Council for Science and Technology.

Tok, S. (2010). The problems of teacher candidate's about teaching skills during teaching practice. Procedia Social and Behavioral Sciences, 2 (3) 4142-4146.

Tortop, H., Uzunkavak, M., \& Ozek, N. (2009). The application of project based learning model supported by prepared according to constructivist approach the field trip to the Solar Energy and its usage areas. Balkan Physics Letters, 16(3) 1-8.

Tüysüz, C. (2010). The Effect of the Virtual Laboratory on Students' Achievement and Attitude in Chemistry. International Online Journal of Educational Sciences, 2(1), 37-53.

ZIMSEC (2012). Biology examination report. Harare: Government Printers.

ZIMSEC (2014). Biology examination report. Harare: Government Printers. 